Supplement of Atmos. Chem. Phys., 19, 5467-5494, 2019

https://doi.org/10.5194/acp-19-5467-2019-supplement

(C) Author(s) 2019. This work is distributed under

the Creative Commons Attribution 4.0 License.

(c) (i)
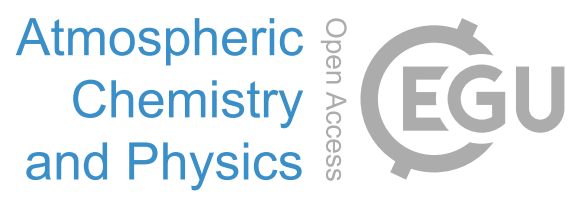

Supplement of

\title{
Ozone source apportionment during peak summer events over southwestern Europe
}

María Teresa Pay et al.

Correspondence to: María Teresa Pay (maria.pay@bsc.es)

The copyright of individual parts of the supplement might differ from the CC BY 4.0 License. 


\section{Contents}

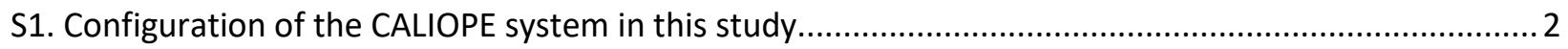

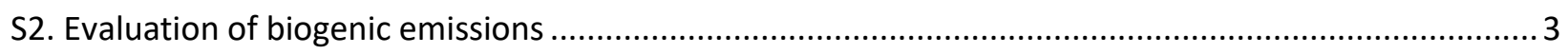

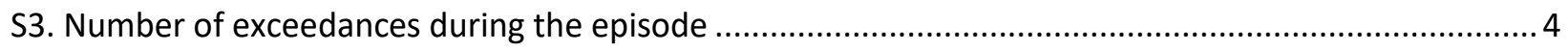

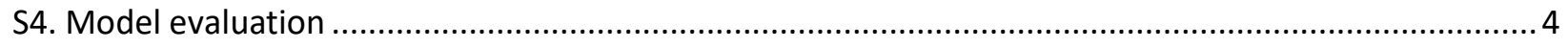

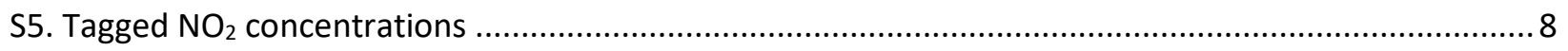

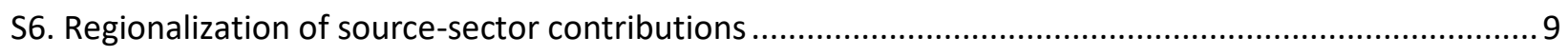

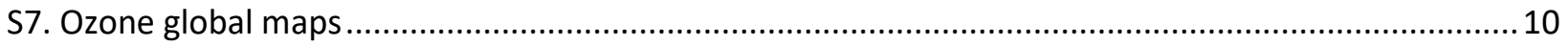




\section{S1. Configuration of the CALIOPE system in this study}

Table S1. Detail set up of the CALIOPE system in the present modelling study

\begin{tabular}{|c|c|}
\hline Meteorological model & WRF-ARWv3.5.1 \\
\hline $\begin{array}{r}\text { Initial and boundary meteorological } \\
\text { conditions }\end{array}$ & GFS-FNL $(1.5 \circ \times 1.5 \circ, 6 h)$ \\
\hline Meteorological spin-up period & 12 hours \\
\hline $\begin{array}{r}\text { WRF mother domain } 12-\mathrm{km} \text { resolution over } \\
\text { Europe }(\mathrm{nx}, \mathrm{ny}, \mathrm{nz})\end{array}$ & $480 \times 400 \times 38$ \\
\hline $\begin{array}{r}\text { WRF nested domain 4-km resolution over the } \\
\text { Iberian Peninsula (nx, ny, nz) }\end{array}$ & $399 \times 399 \times 38$ \\
\hline \multirow[t]{7}{*}{ WRF parametrizations } & Boundary layer: YSU \\
\hline & Microphysics scheme: WSM5 \\
\hline & Cumulus scheme: no cumulus parametrization \\
\hline & Land Surf physics: unified Noah land-surface model \\
\hline & Long Wave: RRTM \\
\hline & Short Wave: Dudhia \\
\hline & Surface Layer: Revised MM5 Monin-Obukhov scheme \\
\hline Emission model & HERMESv2 \\
\hline Base year of the emission & 2009 \\
\hline Chemical Transport Model & CMAQv5.0.2 \\
\hline Chemical mechanism & cb05-TUCL-aero6 \\
\hline Chemical boundary conditions & MOZART4-GEOS5 forecast $(1.70 \times 2.5 \circ, 6 \mathrm{~h})$ \\
\hline CTM spin-up period & 6 days \\
\hline ISAM tracked species & $\mathrm{O}_{3}, \mathrm{NO}_{x}, \mathrm{NMVOC}$ \\
\hline $\begin{array}{r}\text { Mother domain 12-km resolution over } \\
\text { Europe }(\mathrm{nx}, \mathrm{ny}, \mathrm{nz})\end{array}$ & $478 \times 398 \times 15$ \\
\hline $\begin{array}{r}\text { Nested domain 4-km resolution over the } \\
\text { Iberian Peninsula ( } \mathrm{nx}, \mathrm{ny}, \mathrm{nz})\end{array}$ & $397 \times 397 \times 15$ \\
\hline \multirow[t]{4}{*}{ CMAQ parametrizations } & Horizontal advection scheme: Yamartino mass-conserving \\
\hline & $\begin{array}{l}\text { Vertical advection scheme: Piecewise Parabolic Method } \\
\text { (PPM) }\end{array}$ \\
\hline & $\begin{array}{l}\text { Vertical diffusion: Asymmetric Convective Model v2 (ACM2) } \\
\text { Eddy diffusivity approach }\end{array}$ \\
\hline & Dry deposition routine: Models $-3+\mathrm{Cl}$ species \\
\hline
\end{tabular}




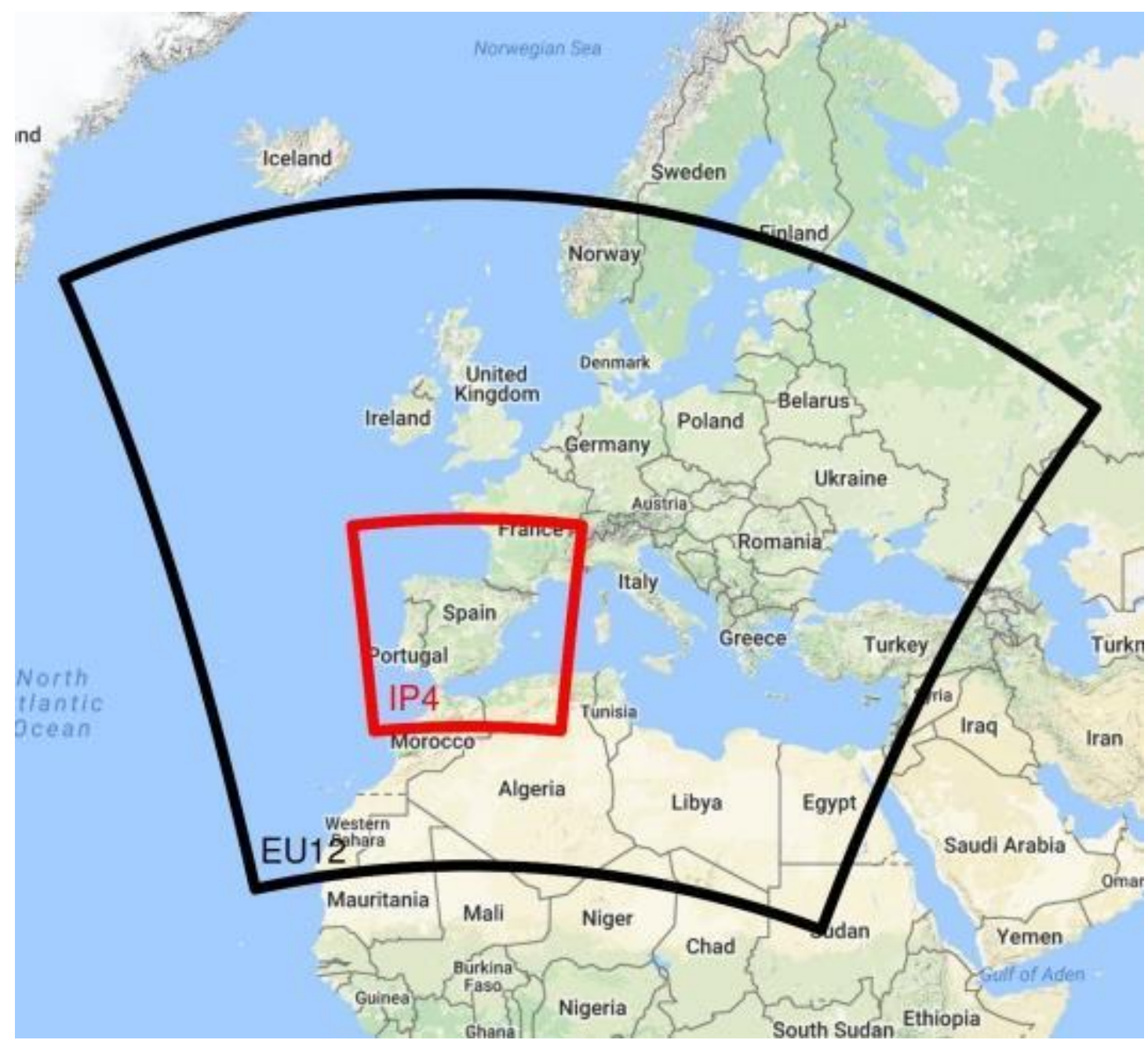

Figure S1. CMAQ domains in the CALIOPE system for the present study. EU12 corresponds to the mother domain at 12-km horizontal resolution (black). IP4 depicts the Iberian Peninsula domain at 4-km horizontal resolution used to run ISAM (red)

\section{S2. Evaluation of biogenic emissions}

Figure S2 shows the isoprene concentration at the Montseny station during the DAURE experimental campaign (Seco et al., 2011; http://cires.colorado.edu/jimenez-group/wiki/index.php/DAURE). Black dots indicate the measured isoprene concentration. Red lines indicate the modelled isoprene by MEGANv2.0.4 with global emission factor inputs files from MEGANv2.1. Blue lines show an experiment where emissions factors are based on local vegetation information. This evaluation indicates that modelled isoprene concentrations with updated emission factors are in reasonably good agreement with observations. 


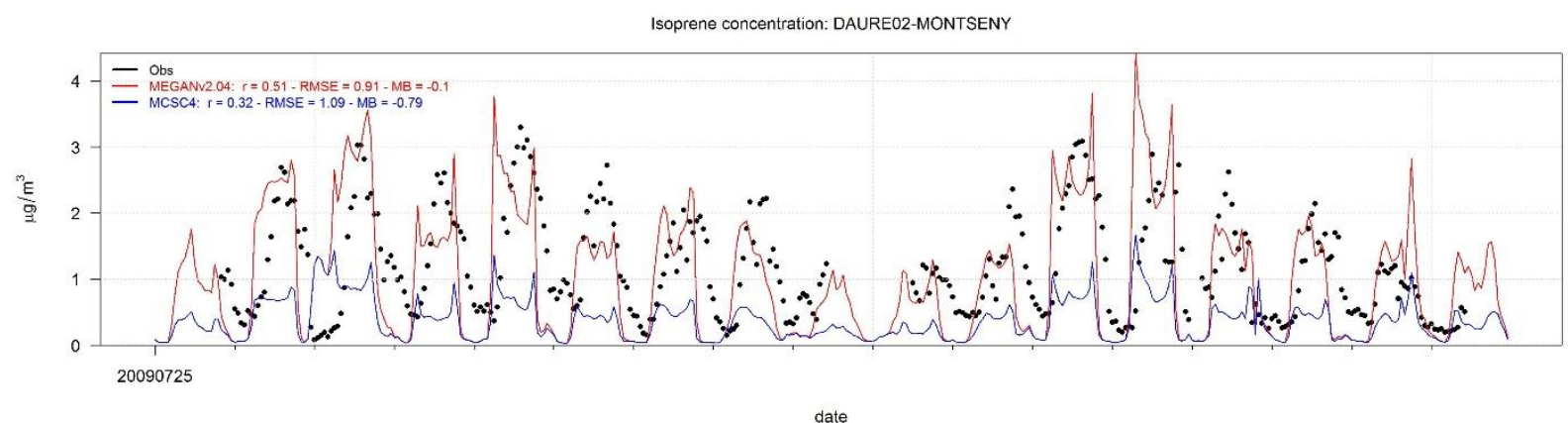

Figure S2. Time series for the isoprene concentration at the Montseny station during the DAURE experimental campaign

References:

Seco, R., Peñuelas, J., Filella, I., Llusià, J., Molowny-Horas, R., Schallhart, S., Metzger, A., Müller, M., and Hansel, A.: Contrasting winter and summer VOC mixing ratios at a forest site in the Western Mediterranean Basin: the effect of local biogenic emissions, Atmos. Chem. Phys., 11, 13161-13179, doi:10.5194/acp-11-13161-2011, 2011.

\section{S3. Number of exceedances during the episode}

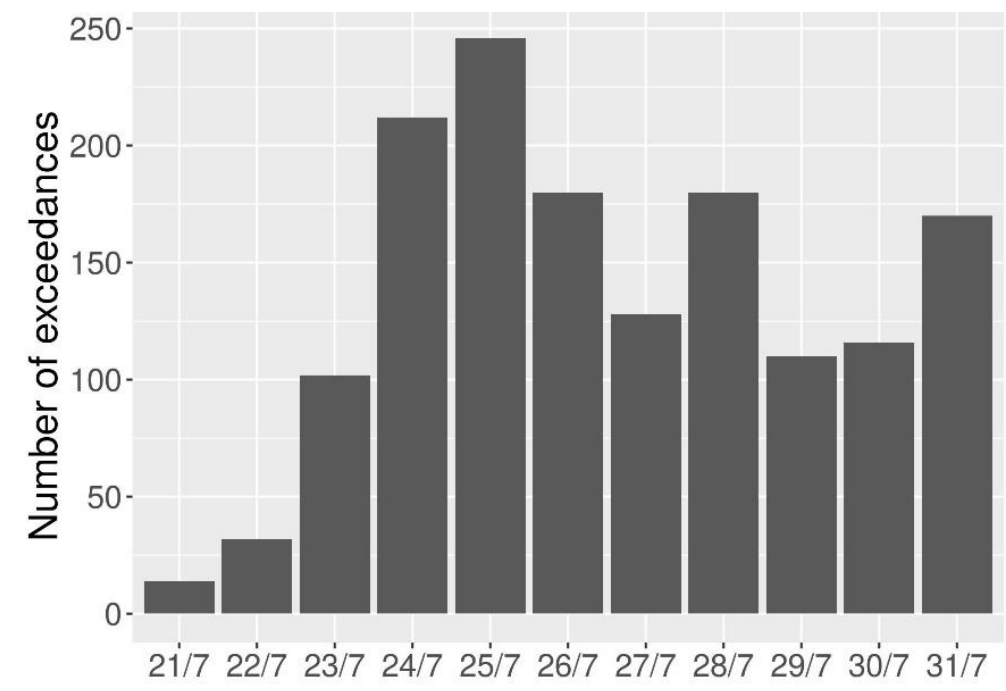

Figure S3. Number of stations exceeding the $\mathrm{O}_{3}$ Target Value $\left(120 \mathrm{\mu gm}^{-3}\right)$ per episode day

\section{S4. Model evaluation}

We evaluate the updated version of CALIOPE using ISAM to quantify the system's ability to reproduce $\mathrm{O}_{3}$ and $\mathrm{NO}_{2}$ concentrations. We evaluate the simulated concentrations against air quality measurements from the Spanish monitoring stations that are part of the European Environment Information and 
Observation Network (EIONET; https://www.eionet.europa.eu/). The EIONET network provides a relatively dense geographical coverage of the Spanish territory. During the July $21^{\text {st }}-31^{\text {st }}$ episode we used the measurements from 347 stations for $\mathrm{O}_{3}$ and 357 stations for $\mathrm{NO}_{2}$ with a temporal coverage above $85 \%$ on an hourly basis. Fig. $\mathrm{S} 2$ shows the distribution of the stations for $\mathrm{O}_{3}$ and $\mathrm{NO}_{2}$. Figure $\mathrm{S} 4$ depicts the $\mathrm{MB}$, RMSE and $r$ for average hourly and $M D A 8 \mathrm{O}_{3}$, and average hourly $\mathrm{NO}_{2}$ concentrations.

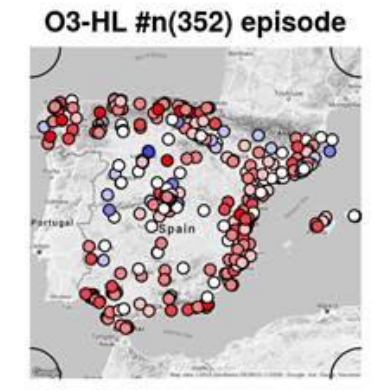

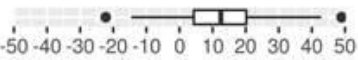
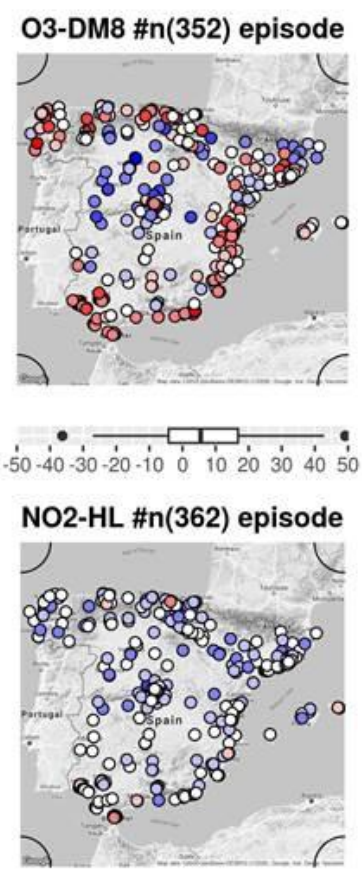

-50-40-30-20-10 0 10

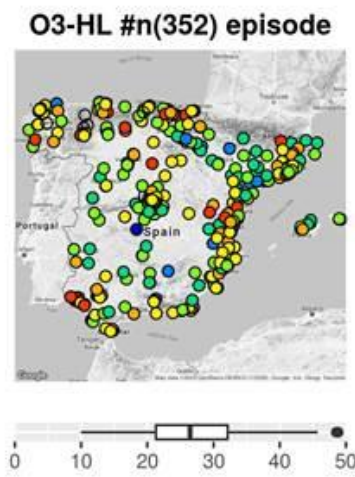

O3-DM8 \#n(352) episode

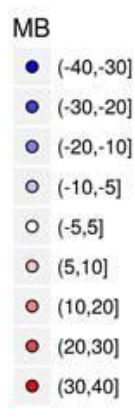

MB

- $(-40,-30]$

- $(-30,-20]$

- $(-20,-10]$

○ $(-10,-5]$

$\circ(-5,5]$

- $(5,10]$

- $(10,20]$

- $(20,30]$

- $(30,40]$

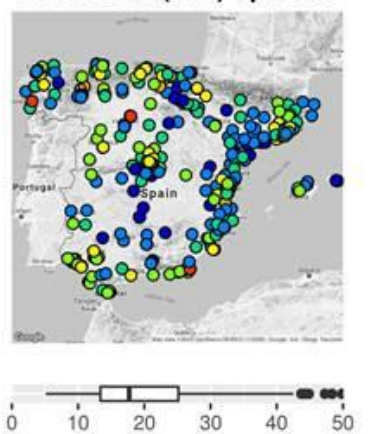

NO2-HL \#n(362) episode

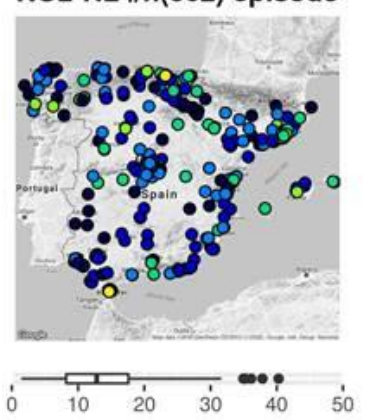

O3-HL \#n(352) episode
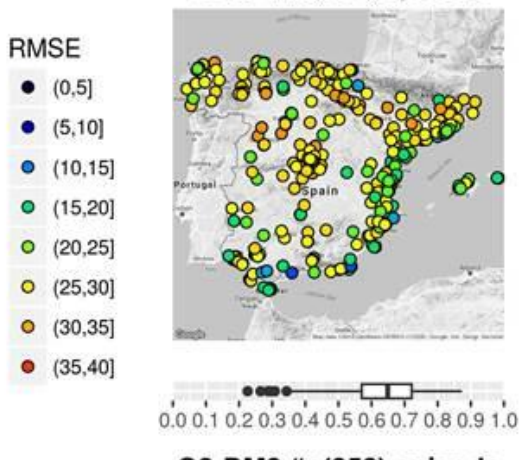

- $(0,0.1]$

- $(0.1,0.2]$

- $(0.2,0.3]$

- $(0.3,0.4]$

- $(0.4,0.5]$

- $(0.5,0.6]$

- $(0.6,0.7]$

○ $(0,7,0.8]$

- $(0.8,0.9]$

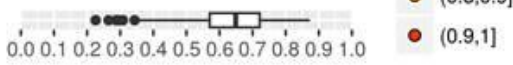

O3-DM8 \#n(352) episode
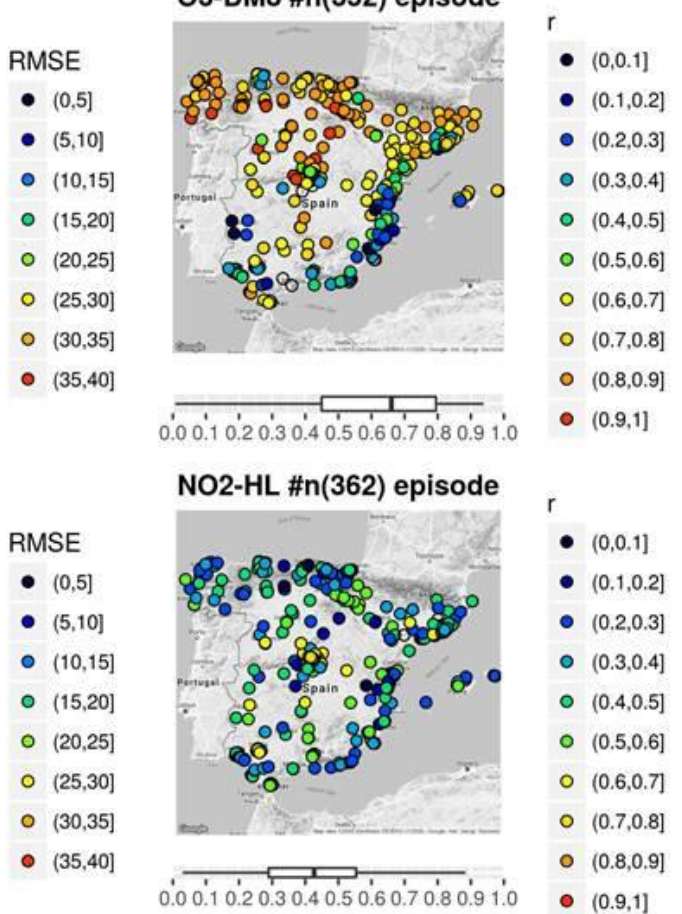

Figure S4. Mean bias (MB, in $\mu \mathrm{g} / \mathrm{m}^{3}$ ) (first column), Root Mean Squared Error (RMSE, in $\mu \mathrm{g} / \mathrm{m}^{3}$ ) (second column) and correlation coefficient (r) (third column) for $\mathrm{HL} \mathrm{O}_{3}, \mathrm{MDA}_{8} \mathrm{O}_{3}$ and $\mathrm{HL} \mathrm{NO}_{2}$ at the Spanish EIONET stations during the selected $\mathrm{O}_{3}$ episode

This section also evaluates the meteorological fields wind speed (WS), wind direction (WD) at $10 \mathrm{~m}$ and temperature at $2 \mathrm{~m}$ (T2M) using METeorological Aerodrome Report stations (METAR). For the selected episode, there were 50 METAR stations located at airports (see location in Fig. S5). Table S2 shows the summary of the statistical evaluation following the methodology explain in "Section 2.4 Evaluation method" for concentrations. 

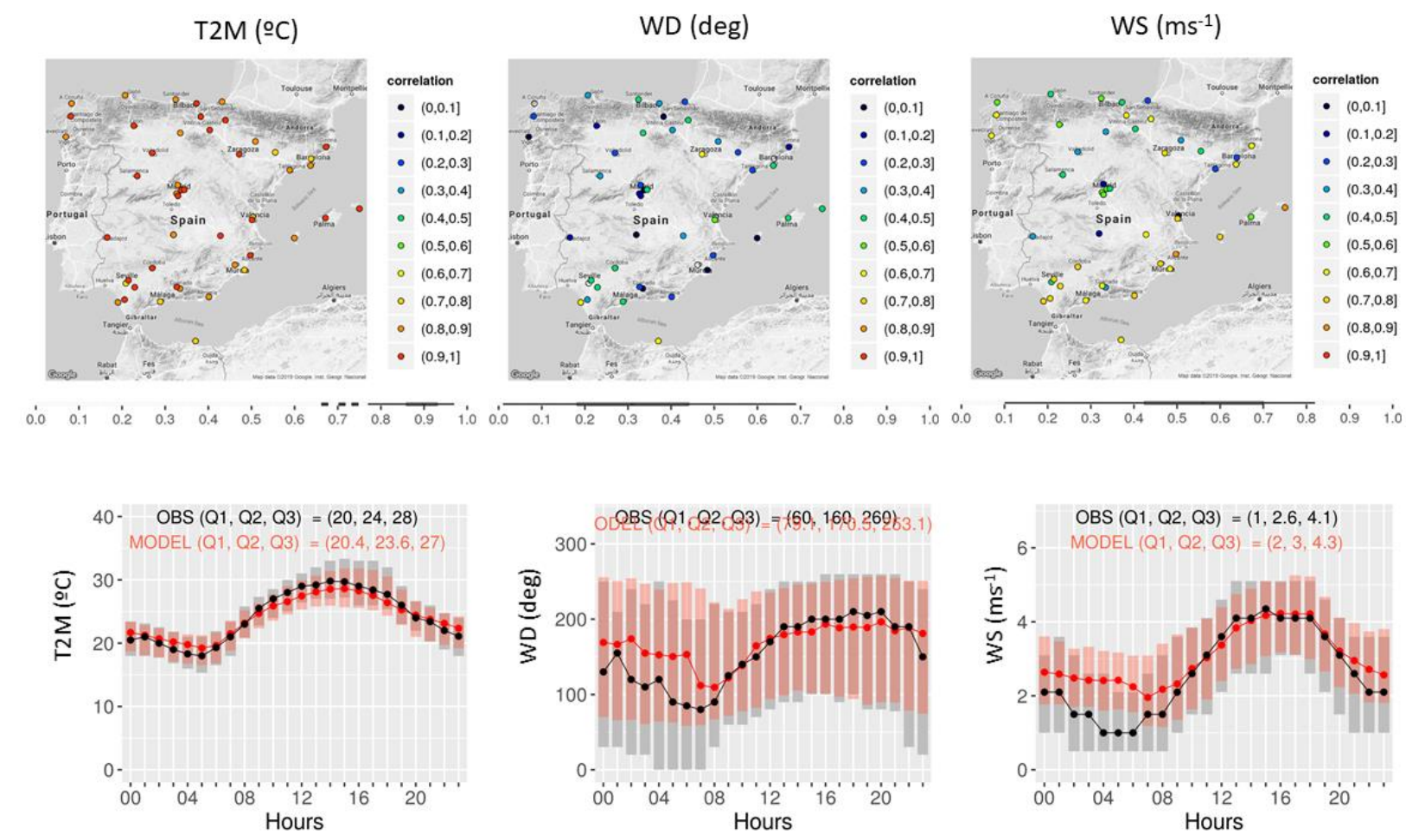

Figure S5. Hourly Temperature at $2 \mathrm{~m}$ (T2M, in 9 C) (first column), Wind Direction (WD, in deg) (second column) and Wind Speed (WS) (third column) at the METAR (METeorological Aerodrome Report) stations over Spain during the selected $\mathrm{O}_{3}$ episode. First row shows the correlation coefficient for each METAR station. Second row shows daily cycles for the meteorological variables for model and observations at the METAR stations. Q1, Q2 and Q3 indicate quartiles for the daily cycle. Bars show Q1 and Q3 at each hour

It is the modelled T2M that shows the best behaviour when compared with observations $(r=0.91)$ (Table $\mathrm{S} 2)$. The model slightly underestimates $\mathrm{T} 2 \mathrm{M}\left(-0.2^{\circ} \mathrm{C}\right)$, especially for maximum and minimum temperatures (1.0ㅇ $\mathrm{C}$ and $0.4{ }^{\circ} \mathrm{C}$ for $\mathrm{p} 25$ and p75, respectively) (Fig. S5). The model reproduces the WS $(r=0.42-0.70)$ with an overestimation of $\sim 0.3 \mathrm{~ms}-1$ on average. The overestimation is particularly marked during nighttime (Fig. S5), coincident with low-level wind speeds. These biases may contribute to the underestimation of surface concentrations of $\mathrm{O} 3$ precursors. The wind direction shows a lower correlation coefficient (0.1, 0.43). As for WS, daily cycle shows the better agreement with observation during the day and problems at nighttime. 
Table S2. Statistics for T2M, WS and WD in the selected $\mathrm{O}_{3}$ episode at the METAR stations. $N$ indicates the number of pairs of data used in the discrete evaluation on an hourly basis and $n$ the number of stations (see Fig.

S2). Statistics are calculated by considering more than $75 \%$ of the hours in a day. The statistics correspond to following quantiles $50^{\text {th }}\left(25^{\text {th }}, 75^{\text {th }}\right)$ by station.

\begin{tabular}{cccccccc}
\hline & $\mathrm{N} / \mathrm{n}$ & $\mathrm{MO}$ & $\mathrm{MM}$ & $\mathrm{MB}$ & $\mathrm{NMB}$ & $\mathrm{RMSE}$ & $\mathrm{r}$ \\
& & & & & $(\%)$ & & \\
\hline \multirow{2}{*}{$\mathrm{T} 2 \mathrm{M}(\mathrm{o} \mathrm{C})$} & \multirow{2}{*}{$12924 / 50$} & 25.0 & 24.4 & -0.2 & -0.9 & 2.3 & 0.91 \\
& & $(22.6,26.1)$ & $(21.7,26.1)$ & $(-0.9,0.2)$ & $(-4.5,0.9)$ & $(1.8,2.7)$ & $(0.86,0.93)$ \\
WD (deg) & \multirow{2}{*}{$12200 / 50$} & 160.3 & 159.9 & 9.6 & 6.2 & 119.45 & 0.27 \\
& & $(131.8,186.9)$ & $(140.4,209,5)$ & $(-10.9,24.7)$ & $(-7.1,16.3)$ & $(101.6,141.5)$ & $(0.1,0.43)$ \\
WS (ms $\left.{ }^{-1}\right)$ & \multirow{2}{*}{$13195 / 50$} & 3.0 & 3.2 & 0.3 & 12.3 & 1.9 & 0.56 \\
& & $(2.5,3.3)$ & $(2.9,3.5)$ & $(-0.1,0.7)$ & $(-3.9,26.1)$ & $(1.6,2.1)$ & $(0.42,0.70)$ \\
\hline
\end{tabular}

Overall, nighttime meteorology remains a challenge for meteorological models. The nighttime systematic overestimation of wind is a potential source of large error compensation for the modelling of $\mathrm{NO} 2$ and $\mathrm{O} 3$ nighttime concentrations.

References:

Vautard, R., Moran, M. D., Solazzo, E., Gilliam, R. C., Matthias, V., Bianconi, R., Chemel, C, Ferreira, J., Geyer, B., Hansen, A.B., Jericevic, A., Prank, M., Segers, A., Silver, J.D., Werhahn, J., Wolke, R., Rao, S.T., Galmarini, S.: Evaluation of the meteorological forcing used for the Air Quality Model Evaluation International Initiative (AQMEII) air quality simulations. Atmospheric Environment, 53, 15-37, 2012.

Bessagnet, B., Pirovano, G., Mircea, M., Cuvelier, C., Aulinger, A., Calori, G., Ciarelli, G., Manders, A., Stern, R., Tsyro, S., Gar- cía Vivanco, M., Thunis, P., Pay, M.-T., Colette, A., Couvidat, F., Meleux, F., Rouïl, L., Ung, A., Aksoyoglu, S., Baldasano, J. M., Bieser, J., Briganti, G., Cappelletti, A., D'Isidoro, M., Fi- nardi, S., Kranenburg, R., Silibello, C., Carnevale, C., Aas, W., Dupont, J.-C., Fagerli, H., Gonzalez, L., Menut, L., Prévôt, A. S. H., Roberts, P., and White, L.: Presentation of the EURODELTA III intercomparison exercise evaluation of the chemistry transport models' performance on criteria pollutants and joint analysis with meteorology, Atmos. Chem. Phys., 16, 12667-12701, doi:10.5194/acp-16-12667-2016, 2016. 
S5. Tagged $\mathrm{NO}_{2}$ concentrations
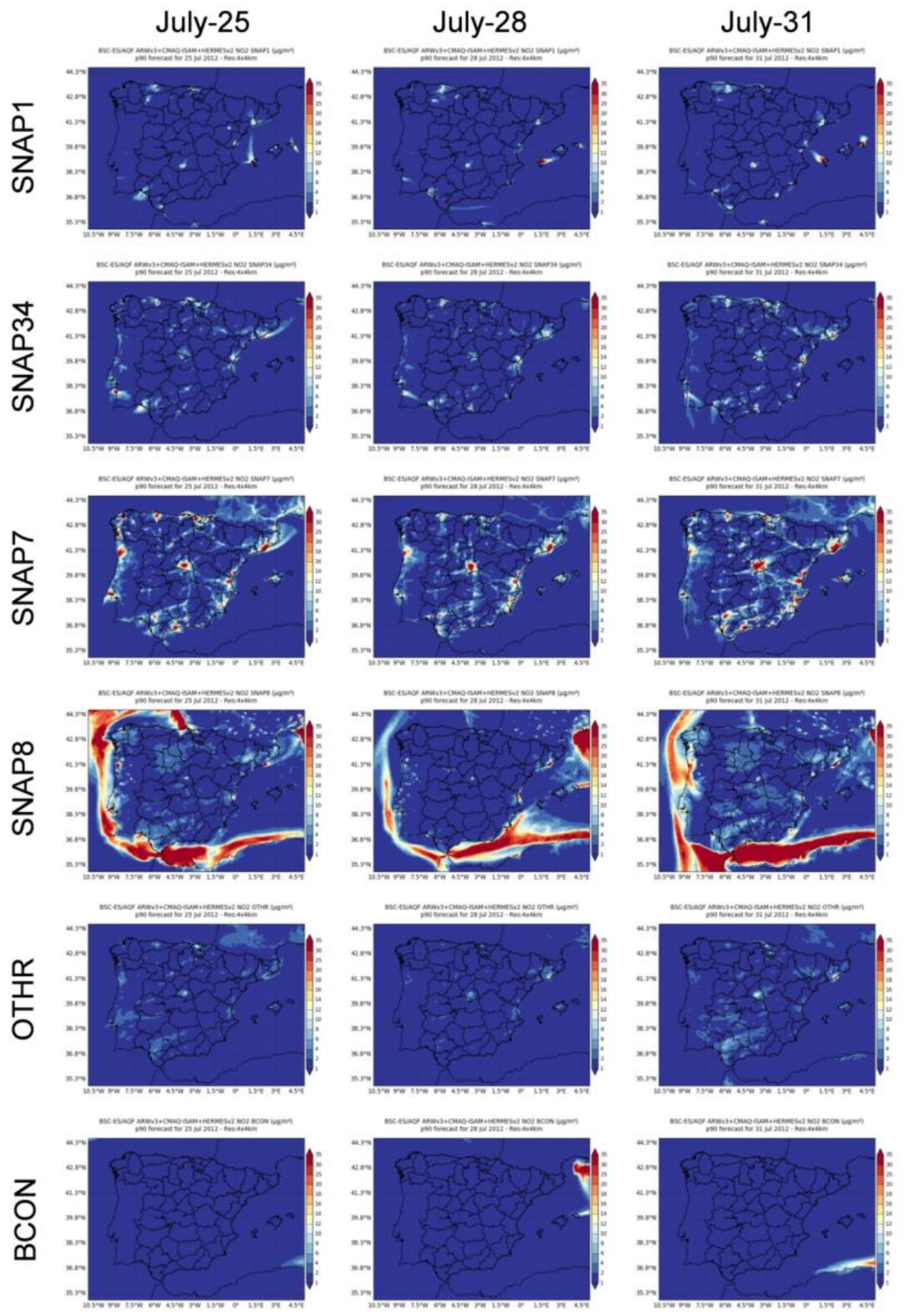

Figure S6. Tagged $\mathrm{NO}_{2}$ concentrations (in $\mu \mathrm{gm}^{-3}$ ) corresponding to the $90^{\text {th }}$ percentile $(90 \mathrm{p}$ ) of the average hourly concentrations: SNAP1, SNAP34, SNAP7, SNAP8, OTHER, and BCON for July $25^{\text {th }}$ (first column), $28^{\text {th }}$ (second column) and $31^{\text {st }}$ (third columns) in 2012 


\section{S6. Regionalization of source-sector contributions}

Table S3. Absolute $\left(\mu_{\mathrm{gm}^{-3}}\right)$ and normalized (\%) contribution of tagged sources to surface $\mathrm{O}_{3}$ concentration by receptor region: Center of the IP (CIP), Eastern IP (EIP), Ebro Valley (EV), Guadalquivir Valley (GV), the Mediterranean Sea (MED), North-Eastern IP (NEIP), Northern IP (NIP), North-Western IP (NWIP), Southern IP (SIP) and Western IP (WIP). Regions are sorted by decrease BCON $\mathrm{O}_{3}$ concentration

\begin{tabular}{|c|c|c|c|c|c|c|c|c|c|c|c|c|}
\hline \multirow{2}{*}{ Zone } & \multicolumn{6}{|c|}{ Concentration $\left(\mu \mathrm{gm}^{-3}\right)$} & \multicolumn{6}{|c|}{ Percentage (\%) } \\
\hline & $B C O N$ & OTHR & SNAP1 & SNAP34 & SNAP7 & SNAP8 & $B C O N$ & OTHR & SNAP1 & SNAP34 & SNAP7 & SNAP8 \\
\hline MED & 77.6 & 2.4 & 2.0 & 1.8 & 9.5 & 8.4 & 76 & 2 & 2 & 2 & 9 & 8 \\
\hline EV & 67.7 & 3.7 & 3.2 & 3.2 & 10.8 & 11.6 & 68 & 4 & 3 & 3 & 11 & 12 \\
\hline EIP & 67.1 & 3.7 & 2.8 & 2.9 & 12.2 & 11.9 & 67 & 4 & 3 & 3 & 12 & 12 \\
\hline NEIP & 62.2 & 5.2 & 2.6 & 4.0 & 16.3 & 13.5 & 60 & 5 & 2 & 4 & 16 & 13 \\
\hline$C I P$ & 59.3 & 5.8 & 2.1 & 4.1 & 17.3 & 10.3 & 60 & 6 & 2 & 4 & 18 & 10 \\
\hline WIP & 59.2 & 5.7 & 2.5 & 3.5 & 12.8 & 9.8 & 63 & 6 & 3 & 4 & 14 & 11 \\
\hline SIP & 58.7 & 4.5 & 3.5 & 2.6 & 14.8 & 19.2 & 57 & 4 & 3 & 3 & 14 & 19 \\
\hline NIP & 56.3 & 5.4 & 2.6 & 4.6 & 14.4 & 11.8 & 59 & 6 & 3 & 5 & 15 & 12 \\
\hline NWIP & 55.7 & 5.8 & 4.4 & 4.5 & 13.6 & 10.3 & 59 & 6 & 5 & 5 & 14 & 11 \\
\hline$G V$ & 49.2 & 8.3 & 5.2 & 6.4 & 18.9 & 18.3 & 46 & 8 & 5 & 6 & 18 & 17 \\
\hline
\end{tabular}

Note: We have excluded the ICON $\mathrm{O}_{3}$ because its contribution is negligible after six days of spin-up. 


\section{S7. Ozone global maps}

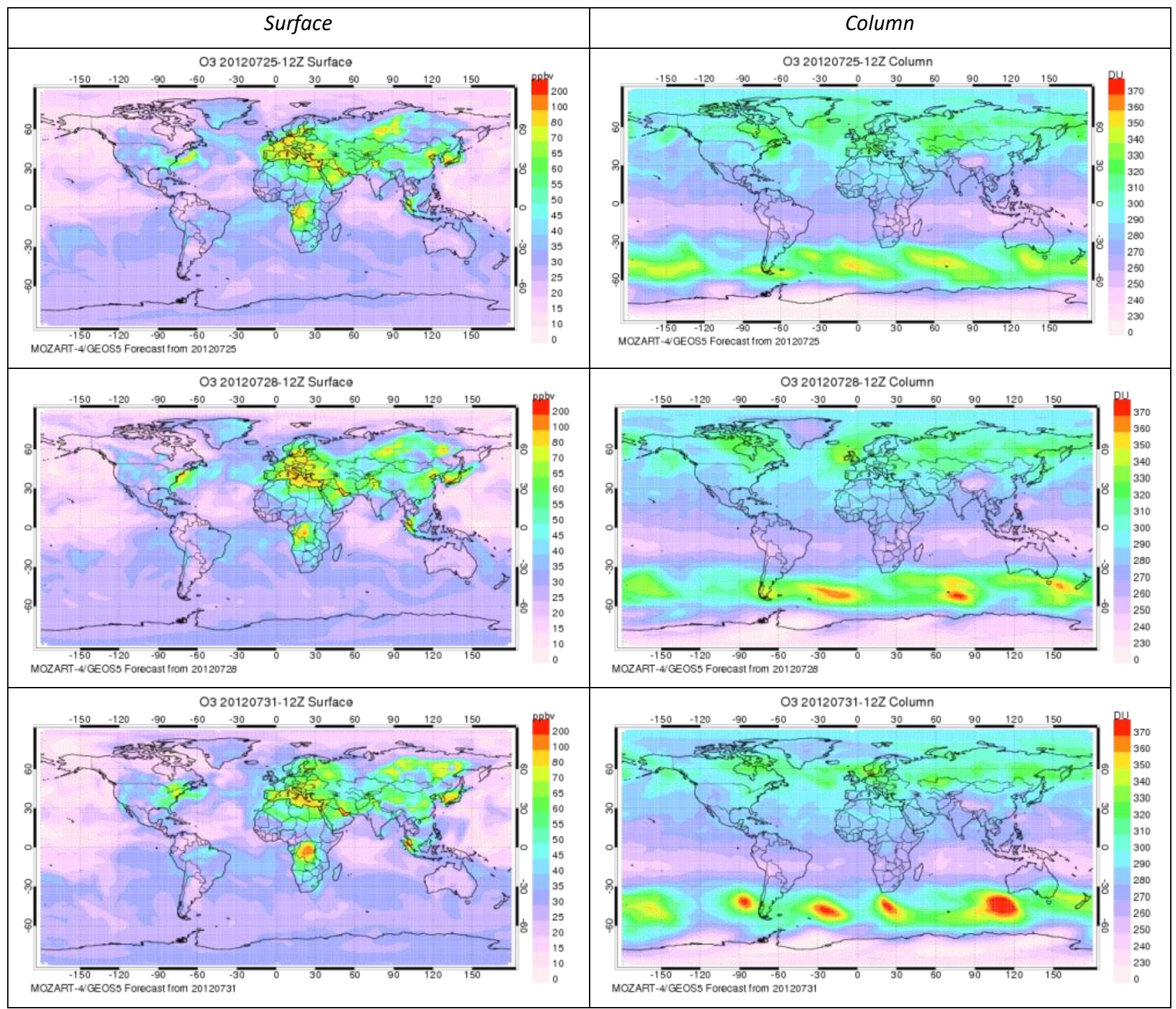

Figure $\mathrm{S7} \mathrm{O}_{3}$ global maps for surface concentration (first column, in ppbv) and column (right column, in DU) for the July $25^{\text {th }}$ (first row), $28^{\text {th }}$ (second row) and $31^{\text {st }}$ (third row) in 2012 for the MOZART-4 model used for CALIOPE boundary condition in the European domain (EU12). Source: http://www.acom.ucar.edu/acresp/forecast/ 